\title{
KONSEP PENDIDIKAN ABAD 21: KEPEMIMPINAN DAN PENGEMBANGAN SUMBER DAYA MANUSIA SD/MI
}

\author{
Ahmad Tarmizi Hasibuan \\ Andi Prastowo \\ Pasca Sarjana Fakultas Ilmu Tarbiyah dan Keguruan \\ Universitas Islam Negeri Sunan KalijagaYogyakarta \\ roszi0508@gmail.com
}

\begin{abstract}
Abstrak
Perubahan pola pendidikan yang terasa pada saat ini merupakan salah satu ciri era globalisasi atau disebut dengan era keterbukaan (era of oppenes), ini dibuktikan dengan berkembangnya Ilmu Pengetahuan (science) dan Teknologi (tecnology). Era ini sering disebut dengan abad 21. Abad 21 lebih menekankan atau menuntut dalam menciptakan kualitas sumber daya manusia. Oleh karenanya tujuan artikel ini adalah untuk mengkaji bidang pendidikan dan menambah pemahaman pemimpin atau kepala sekolah tentang abad 21 baik dari segi karakteristik, elemen dan relevansinya untuk mengembangkan mutu sumber daya manusia di era globalisasi yang penuh dengan tantantangan persaingan serta menuntut keahlian. Penelitian ini menggunakan penelitian library research dengan membaca buku-buku terkait dengan metode studi kepustakaan. Adapun temuan peneliti tentang karakteristik abad 21: 1). Kreatif dan inovatif (creative and innovative), 2) Sifat berfikir kritis (the nature of critical thinking), 3) Pengintegrasian ilmu (integration of science), 4) Mudah mendapatkan informasi (easy to get knowledge), 5) Berjiwa komunikatif dan kolaboratif (communicative and collaborative spirit), 6) Menghargai perbedaan pendapat (respect differences of opinion), dan 7) pendidikan sepanjang hayat (longlife education). Dari segi elemen abad 21: 1) Membentuk sumber daya manusia yang berkualitas, dan 2) Belajar sepanjang hayat. Sedangkan dari segi relevansi kepemimpinan dalam mengembangkan sumber daya manusia SD/MI: 1) Memanfaatkan teknologi untuk mencari sumber informasi, 2) Berkomunikasi dan berkerjasama, 3) Kreatif dalam proses pembelajaran, 4) Menanamkan literasi, 5) Menghargai pendapat dan berfikir kritis, 6) Mengembangkan berbagai pembelajaran secara inovatif serta 7) Menjadi manusia pembelajar sesuai dengan konsep pendidikan sepanjang hayat.
\end{abstract}

Kata Kunci: Pendidikan, Abad 21, Sumber Daya Manusia

Abstract

Changes in education pattern nowdays is one of the characteristics in globalization era or openness era, it is evidenced by the development of Science and Technology. This era usually called the 21 st century. The 21 st century will emphasize or demand more in creating the quality of human resources. Therefore the purpose of the article is to study the field of education in the 21 st century both in terms of its characteristics, elements and relevance in 
developing the quality of human resources. This research uses research library research by reading books related to the library study method. The characteristics of the 21st century: 1). creative and innovative, 2) nature of critical thinking, 3) integration of science, 4) easy to get information, 5) communicative and collaborative spirit, 6) Respect for differences of opinion and 7) longlife education. Elements and Characteristics of the 21 st century: 1) Establish the quality human resources, and 2) Lifelong learning. While leadership relevance in developing SD/MI human resources: 1) Utilizing technology to find information sources, 2) Communicating and collaborating, 3) Creative in the learning process, 4) Installing literacy, 5) Respecting opinions and critical thinking, 6) Developing a variety of innovative learning and 7) Become a human learner in accordance with the concept of lifelong education.

Keywords: Education, 21 st Century, Human Resources

\section{A. PENDAHULUAN}

Konsep pendidikan awalnya sudah ditanamkan dalam Alquran. Alquran sudah memberikan perubahan yang signifikan dalam mengembangkan pendidikan. Pendidikan terkonsep dalam surat Al-alaq ayat 1-5. Surat tersebut mengajarkan manusia untuk selalu membaca kondisi dan situasi yang ada dalam tataran kehidupan tidak terkecuali pendidikan. Pendidikan di Indonesia notabene masih dalam kondisi memprihatinkan. Hal ini berbeda dengan Negeri Sakura (Jepang) yang sudah mampu untuk menciptakan benda elektronik seperti robot. Hasil ini yang dapat membuktikan kelulusan atau tidaknya anak didik, berbeda dengan Indonesia yang masih mengacu pada nilai raport. ${ }^{1}$

Hal ini sesuai dengan penelitian Scott yang menunjukkan bahwa lulusan Indonesia sangat kurang kompoten dalam berbagai hal seperti komunikasi, bekerjasama hingga bersosial. ${ }^{2}$ Ditambah dengan hasil survey yang dilakukan 2014 oleh ASEAN Business Outlook yang memaparkan hasil laporannya dan menyatakan bahwa Negara Maritim (Indonesia) menjadi tujuan investasi terbesar untuk Negara Asing terutama di Wilayah Asia Tenggara. Hal ini mengindikasikan bahwa

\footnotetext{
${ }^{1}$ Katrina Ananiadou and Magdalean Cloro, 21st Century Skills and Competences for New Millennium Learners in OECD Countries. (OECD Education Working Papers, No. 41, 2009 Paris, OECD Publishing, hlm 5-6.

${ }^{2}$ Cynthia Luna Scott. The Futures of Learning 1: Why Must Learning Content and Methods Change In The 21st Century? UNESCO Education Research and Foresight, Paris. ERF Working Papers Series, No. 13, 2015, hlm 11.
} 
kurangnya sumber daya manusia di Negara Indonesia, tidak terkecuali guru. Negara Indonesia sangat sering merubah dan mengalami perubahan pola pendidikan baik dari segi kurikulum, bahan ajar, metode dan pembawaan atau teknik dalam menyampaikan pembelajaran, sehingga masih monoton dalam pengimplementasian untuk mewujudkan sumber daya manusia yang diinginkan di Abad 21.

Perubahan pola pendidikan pada abad 21 yang terasa pada saat ini merupakan salah satu ciri era globalisasi atau disebut dengan era keterbukaan (era of oppenes), ini dibuktikan dengan berkembangnya Ilmu Pengetahuan (science) dan Teknologi (tecnology). ${ }^{3}$ Seorang guru harus memiliki satu langkah perubahan dalam abad ini, seperti merubah teknik tradisional (ceramah) yang berpusat pada guru, menjadi lebih kreatif dan inovatif sehingga lebih berpusat pada siswa agar mampu mengembangkan mutu sumber daya manusia (SDM) dan mutu pendidikan.

Guru yang diharapkan mampu mengembangkan potensi mutu pendidikan tercantum dalam slogan Ki Hajar Dewantara yang termaktub di slogan Kementerian Pendidikan dan Kebudayaan (Tut Wuri Handayani), yaitu:

Guru yang sering disebut pendidik diwajibkan memiliki peran untuk mendorong siswa secara aktif dalam mengembangkan potensi yang dimiliki peserta didik dan mampu menjadi model dalam pembelajaran atau tauladan (leaner model), serta guru harus mengikuti perkembangan arus pendidikan alakhir, yang sebenarnya guru dan murid mampu belajar bersama. ${ }^{4}$

Berdasarkan proposisi di atas dapat dimengerti bahwa guru bukan hanya menjadi panutan dalam mengeksperesikan suatu materi saja, namun harus mampu mengelola dan mengikuti alur pendidikan sesuai dengan perkembangan zamannya. Perkembangan zaman yang dimaksud adalah perkembangan Ilmu pengetahuan terakhir. Pendidikan terakhir abad ini disebut dengan Abad 21. Abad yang dipenuhi dengan Ilmu Pengetahuan dan Teknologi yang dapat merubah tata kehidupan pada hlm 4.

${ }^{3}$ Ace Suryadi, Pendidikan, Investasi SDM, dan Pembangunan, Jakarta: Balai Pusataka, 2002,

${ }^{4}$ Badan Standar Nasional Pendidikan, Paradigma Pendidikan Nasional Di Abad-21, Jakarta: BSNP, 2010, hlm 36. 
sebelumnya. Dikatakan Abad 21, karena abad ini meminta kualitas sumber daya manusia. Oleh karenanya lembaga-lembaga harus mampu mengembangkan potensipotensi yang ada, agar menjadi ciri khas tersendiri dalam lembaga, serta mampu mencetak output yang unggul.

Butuhnya peran pendidikan dalam mengembangkan sumber daya manusia sudah tertuang dalam Undang-Undang 1945 yang tujuannya untuk pembangunan Nasional. ${ }^{5}$ Dengan kata lain tanpa bangsa yang cerdas tidak mungkin bangsa ikut dalam persaingan pengetahuan di tengah abad berajang skill. Berbeda dengan abad dahulu, pada abad 21 guru diharapkan mampu menggunakan informasi dan teknologi untuk mengembangkan potensi anak agar dapat mewujudkan bangsa yang berkualitas serta mampu bersaing dengan berbagai bangsa di kancah Internasional.

Abad 21 memiliki perubahan yang sangat fundamental terkhusus dalam dunia pendidikan. Pendidikan merupakan esensi untuk memajukan suatu bangsa, oleh karenanya walau zaman sudah berbeda guru harus mampu membuktikan bahwa perbedaan zaman bukan menjadi suatu tantangan dalam mengembangkan bakat dan potensi anak didik dalam era globalisasi. Abad ini memiliki tuntunan yang sangat tinggi untuk menciptakan sumber daya manusia, oleh karenanya guru harus memiliki inovasi dalam proses pembelajaran. Banyaknya literatur dan penelitian yang membahas tentang konsep pendidikan abad 21 membuat para pendidik dalam penerapanya kesusahan, sehingga menjadi problem dalam proses pembelajaran (kelas, lingkungan, dan lembaga).

Oleh karenanya dengan penulisan artikel ini semoga mampu menjawab tantangan yang ada terutama dalam abad 21. Tujuan tulisan ini adalah untuk membahas bagaimana karakteristik pendidikan abad 21 untuk merumuskan elemen

\footnotetext{
${ }^{5}$ Mangkunegara, A.P, Perencanaan dan Pengembangan Sumber Daya Manusia, Bandung: Rifeka Aditama, 2011, hlm 2
} 
dan karakteristik serta relevansinya dalam mengembangkan mutu sumber daya manusia.

\section{B. METODE PENELITIAN}

Rancangan penelitian yang digunakan peneliti menggunakan pendekatan kualitatif. Hal ini karena penelitian ini menggunakan metode studi kepustakaan (Library Research) dengan mendeskripsikan buku-buku bacaan yang terkait sesuai objek kajian pendidikan Abad 21. Tahapan penelitian diawali dengan membaca beberapa literatur dan mengkajinya dengan berdiskusi serta menganalisis substansi isi materi yang terkait dalam buku tersebut agar mampu menuliskan artikel ini. Oleh karena itu, pengecekan data dalam penelitian ini dilakukan dengan menggunakan bahan referensi yang relevan dengan abad 21 .

\section{HASIL DAN PEMBAHASAN}

\section{Karakteristik Pendidikan Abad 21}

Abad 21 memiliki perubahan yang sangat besar dalam dunia tidak terkecuali dengan Negara Indonesia. Perubahan pemikiran yang menyebar terkhusus dalam arus informasi dan teknologi telah dirasakan pada abad ini. Manusia mengenal abad 21 dengan sebutan abad pengetahuan yang menjadikannya landasan utama dalam berbagai aspek terutama dalam kehidupan bersosial. Pola pemikiran abad 21 menekankan siswa agar lebih berfikir kritis, mampu mengintegrasikan segala ilmu dengan kehidupan nyata, memahami teknologi, dan informasi serta cakap dalam berkomunikasi dan berkolaborasi.

Hal ini senada dengan pendapat Sjafriani yang menyatakan bahwa:

Abad 21 lebih menuntut anak didik dalam segala dua aspek yaitu, kognitif dan psikomotorik. Pendidikan pada masa ini sangat dituntut untuk berfikir kritis dan positif (critical and fositive thingking), menghubungkan segala ilmu (connect all knowledge), mampu mengusai Teknologi dan Informasi (able to master tecnologhy and 
information), serta mampu berkomunikasi dan berkolaborasi (able to communication and cooperate). ${ }^{6}$

Dapat diambil proposisi bahwa kegiatan pada abad 21 lebih menekankan pada aspek kemampuan sumber daya manusia, oleh karenanya tidak menutup kemungkinan interaksi antar bangsa terjadi dan meluasnya informasi serta keterbukaan terjalin tidak terkecuali aspek perkonomian.

Hal ini selaras dengan pendapat Hermawan dalam bukunya yang menuliskan bahwa:

Pendidikan abad 21 akan melebur dalam dimensi "ruang dan waktu" seperti tidak adanya dinding dalam mendapatkan suatu informasi antara negara baik dalam aspek interaksi, pengetahuan, keterbukaan, politik bahkan ekonomi. Meningkatnya perbedaan antara generasi muda dan tua, adanya peningkatan kepedulian yang harus dijaga dan diseimbangkan serta sadar untuk saling keterbutuhan antar negara. ${ }^{7}$

Pernyataan tersebut selaras dengan penelitian Carneiro dan Draxler yang menuliskan bahwa:

Kompetensi yang ada di dalam abad 21 merupakan keadaaan yang seharusnya diantisipasi oleh guru. Guru yang memiliki tugas sebagai fasilitator seharusnya lebih memahami keadaan yang diinginkan masa depan tidak terkecuali era globalisasi yang meminta keahlian kepada setiap individu manusia sehingga mampu bersaing. ${ }^{8}$

Berdasarkan proposisi di atas dapat diambil kesimpulan bahwa pendidikan abad 21 memiliki beberapa karakteristik diantaranya: kreatif dan inovatif (creative and innovative), sifat berfikir kritis (the nature of critical thinking), pengintegrasian ilmu (integration of science), mudah mendapatkan

\footnotetext{
${ }^{6}$ Ririn Sjafriani, Pendidikan Global: Menggunakan Teknologi untuk Memperkenalkan Dunia Global kepada Para Siswa, Jakarta: 2011, hlm 21.

${ }^{7}$ Asep Herry Hernawan, Pengembangan Kurikulum dan Pembelajaran. Jakarta: UT Departemen Pendidikan Nasional, 2006, hlm 41.

${ }^{8}$ Roberto Carneiro and Alexandria Draxler. Education for the 21st century: lessons and challenges. European Journal of Education, Vol. 43, No. 2, 2008, hlm 146-149.
} 
informasi (easy to get knowledge), berjiwa komunikatif dan kolaboratif (communicative and collaborative spirit), menghargai perbedaan pendapat (respect differences of opinion) dan pendidikan sepanjang hayat (longlife education). Karakteristik tersebut dapat diuraikan sebagai berikut:

\section{a. Kreatif dan Inovatif (creative and innovative)}

Perkembangan ilmu pengetahuan dan teknologi yang terjadi pada abad 21 bukan menjadi masalah atau problem bagi guru, namun menjadi acuan untuk perubahan awal dalam dunia pendidikan terkhusus bagi guru dalam mengembangkan kemampuan atau potensi anak didik. Pendidikan abad 21 yang dikenal dengan super highway dalam mendapatkan informasi dan menggunakan media teknologi.

Kemajuan teknologi dan mudahnya mengakses informasi seharusnya mampu memudahkan guru dalam menjelaskan materinya, sehinga sesuai dengan konsep pendidikan pada abad 21 yaitu yang pembelajaran berpusat pada siswa. ${ }^{9}$ Maksudnya guru hanya menjadi fasilitator dalam mengkoneksikan atau menjadi narahubung antara pengetahuan awal siswa. Dalam abad yang dikenal dengan era pengetahuan, digital atau industry, membuat tugas guru semakin mudah bila dijalankan sesuai dengan perkembangan pendidikan, namun sebaliknya dapat menjadi masalah bila tidak mampu berkreasi tentang menggunakan metode untuk memudahkan siswa memahami suatu pelajaran. Hal ini selaras dengan temuan Catherine yang yang menuliskan bahwa guru juga sangat diminta untuk mampu berkontribusi lebih dalam menciptakan suasana belajar yang kreatif dan

\footnotetext{
${ }^{9}$ Damayanti dan Ridwan, isu dalam Sains dan Agama, Yogyakarta: Universitas Islam Negeri Sunan Kalijaga, 2006, hlm 2.
} 
memiliki perubahan atau sifat membangun agar anak tidak bosan nyaman belajar. ${ }^{10}$

Dengan kata lain bahwa guru bukan menjadi suri tauladan atau model dalam proses pembelajaran, namun harus memiliki jiwa berkreatif dan jiwa berinovasi dalam mengembangkan potensi-potensi anak didik, serta mengoptimalkan proses belajar-mengajar dalam suatu pembelajaran.

\section{b. Sifat berfikir kritis (the nature of critical thinking)}

Dunia yang sangat canggih diharapakan guru dan khususnya siswa tidak sulit untuk mencari informasi serta mampu mengelolanya dan diharapkan para siswa tidak lagi hanya berfokus pada teori, namun lebih dalam pengaplikasiannya. Jiwa inilah yang harus ditanamkan oleh guru kepada peserta didik agar lebih mandiri dan menanamkan literasi kepada anak-anak bahkan masyarakat. Guru yang diharapkan mampu meningkatkan kualitas sumber daya manusia (outcome), seharusnya lebih berkompeten dan memiliki jiwa inovasi dalam proses pembelajaran yang sesuai dengan standar keguruan.

Hal ini senada dengan pendapat Sudriarja dalam bukunya yang menyatakan bahwa pendidik merupakan kunci kesuksesan (to key to success) yang mampu menentukan arah kualitas pendidikan bangsa. ${ }^{11}$ Perihal ini juga didukung oleh temuan Stephanou dan Maria yang menyatakan bahwa pembelajaran dengan mengajarkan siswa berfikir kritis agar anak mampu mengasah segala pengalaman yang didapati oleh siswa itu sendiri. ${ }^{12}$

${ }^{10}$ McLoughlin, Catherine, Lee, and Mark .J.W. The Three P's of Pedagogy for the Networked Society: Personalization, Participation, and Productivity, International Journal of Teaching and Learning in Higher Education, Vol. 20, No. 1, 2008, hlm 10-21.

${ }^{11}$ A. Sudriarja, Pendidikan dalam Tantangan Zaman, Yogyakarta: Kanisius, 2014, hlm 3.

12 Georgia Stephanou and Maria-Helena Mpiontini. Metacognitive Regolution in-SelfRegulatory Learning Style, and Its Effects on Performance Expectation and Subsequent Performance across Diverse School Subject, Journal Psychology, Vol.8, No.12, 2017, hlm 23 
Dengan kata lain, peran pendidik tidak bisa dihilangkan begitu saja, karena tanpa pendidik ilmu tidak bisa disampaikan secara menyeluruh sesuai dengan fungsinya (mendidik, mengelola, dan mengevaluasi).

\section{c. Pengintegrasian Ilmu (integration of socience)}

Berbicara ilmu sebenarnya sudah sangat lama diajarkan oleh Tuhan, namun tugasnya untuk mengajarkan diberikan oleh manusia. ${ }^{13}$ Sedangkan dalam integrasinya Tuhan mengajarkannya melalui malaikat Jibril untuk manusia (Nabi Muhammad) yang terkonsep dalam membaca dunia nyata. ${ }^{14}$ Hal ini senada dengan temuan Trelling dan Fadel bahwa mengkaitkan pembelajaran sangat dapat memudahkan anak dalam memahami sesuatu apalagi mengintegrasikannya dengan musik dan nyayian. ${ }^{15}$ Tugas guru bukan hanya mendidik namun harus lebih menanamkan dalam diri siswa untuk membaca situasi dan kondisi yang dialami pada abad yang dikenal dengan abad pengetahuan.

Abad yang dikenal dengan abad pengetahuan (age knowledge) seharusnya bukan menjadi tantangan bagi guru, namun sebaliknya. ${ }^{16}$ Fungsi guru yang notabe adalah mendidik, harus lebih mampu mengintegrasikan ilmu yang ada, agar mampu mengembangkan keilmuwan para siswa. Apalagi pendidikan di Indonesia memiliki pembelajaran tematik (Ilmu Pengetahuan Alam, Matematika, Bahasa Indonesia dan Ilmu Pengetahuan Sosial) pada jenjang usia dasar. Oleh karenanya pendidik yang bertugas untuk mendidik, harus mampu mengkonsep berbagai tema (ilmu) dengan pembelajaran yang

${ }^{13}$ Dapartemen RI. Al-Qur'an dan Terjemah..., hlm 31.

${ }^{14}$ Ibid., hlm 597

${ }^{15}$ Bernie Trilling and Charles Fadel. 21st Century Skills: Learning for Life in Our Times, John Wiley \& Sons, 978-0-47-055362-6, 2009.

${ }^{16}$ Andi Prastowo, Menyusun Rencana Pelaksanaan Pembelajaran (RPP) Tematik Terpadu, Jakarta: Kencana, 2015, hlm 15. 
ada, serta mampu menggunakan berbagai metode sehingga mampu menciptakan suasana belajar yang nyaman.

\section{d. Mudah mendapatkan informasi (easy to get knowledge)}

Perkembangan media teknologi dan informasi menjadi landasan utama serta yang melatarbelakangi abad 21. Abad 21 memperkenalkan manusia pada sistem yaitu teknologi seperti internet yang sering digunakan dalam kegiatan sehari-hari. Penggunaan internet terkhusus Indonesia mengalami peningkatan yang signifikan dalam penggunaanya dalam mencari informasi. Penggunaan teknologi harus digunakan sebenar-benarnya agar dapat mewujudkan manusia pembelajar. Dengan berkembanganya teknologi guru harus mampu mengoperasikan dalam pembelajaran, sehingga tidak hanya menggunakan teknik tradisional.

Karakteristik ini yang mengakibatkan perubahan yang sangat fundamental dalam tataran kehidupan yang diharapkan mampu menyeimbangkan dalam proses pembelajaran, tidak dengan sebaliknya yang dapat merusak karakter bangsa. ${ }^{17}$ Berkembanganya teknologi dan mudahnya mengakses informasi diyakini mampu untuk mewujudkan tujuan pendidikan. Pendidikan yang dipercaya mampu mengangkat derajat suatu bangsa harus dioptimalkan sesuai dengan perkembangan teknologi dan informasi.

e. Berjiwa komunikatif dan kolaboratif (communicative and collaborative spirit)

Manusia yang esensinya adalah makhluk sosial, sudah seharusnya mampu membangun kerjasama antara satu dengan yang lain tidak terkecuali pada abad 21. Salah satu faktor yang mendorong dalam menjalin hubungan kerjasama adalah komunikasi. Komunikasi yang baik diharapkan mampu menambah wawasan, untuk dapat berkomunikasi pada abad ini diharuskan

17 Didin Kurniadin dan Imam Machali, Manajemen Pendidikan: Konsep dan Prinsip Pengelolaan Pendidikan, Jogyakarta: Ar-Ruzz Media, 2014, hlm 102. 
bagi manusia memiliki bahasa yaitu bahasa Inggris dan Arab. Kedua bahasa ini, diharapkan dan harus ditanamkan dalam diri siswa, agar siswa nantinya dapat berintraksi baik dalam dunia nasional maupun internasional. Sebagaimana Trelling dan Fadel menyebutkan bahwa manusia pasti menjadi sukses ketika mampu mengintegrasikan berbagai knowledge di berbagai macam kondisi dan situasi yang ada.

Setelah mampu berkomunikasi yang diharapakan pada abad 21 yaitu menjalin hubungan kerjasama atau membangun jaringan (networking) agar mampu bersaing dengan bangsa-bangsa lain. ${ }^{18}$ Membangun kerjasama antar negara bukan seperti membalikkan telapak tangan. Oleh karenanya manusia diajarakan untuk terlebih dahulu memahami ras, budaya dan kepercayaan (antar ummat beragama), sehingga tidak ada kesalahpahaman nantinya dalam membangun atau (teamwork).

\section{f. Menghargai perbedaan pendapat (respect differences of opinion)}

Abad 21 dikenal dengan ilmu pengetahuan (society) ${ }^{19}$. Perbedaan pendapat pada abad ini pasti terjadi, namun pendidik harus lebih cerdas dalam menyikapinya. Oleh karenanya diharapkan bagi calon pendidik dan pendidik harus mampu memfilter segala pendapat seseorang tanpa harus mengatakan “tidak" kepada yang berpendapat.

Menghargai perbedaan pendapat merupakan salah satu kunci dalam menjalin hubungan kerjasama agar terciptanya jaringan untuk berbagi ilmu pengetahuan, ekonomi maupun lain sebagainya. Untuk itu setiap manusia harus memilki jiwa yang besar dalam menyaring informasi, walau ada

\footnotetext{
${ }^{18}$ Etiska Ayu Wijaya, Dwi Agus Sudjimat dan Amat Nyoto, Transformasi Pendidikan Abad 21 sebagai Tuntunan Pengembangan Sumber Daya Manusia di Era Global, Jurnal: Universitas Negeri Malang, Volume 1 Tahun 2016, hlm 11.

19 Y. M. Sastrapraredja, Pendidikan Multidimensional, Yogyakarta: Sanata Dharma University Press, 2015, hlm 75.
} 
perbedaan antara bahasa, suku atau ras, budaya bahkan kepercayaan dalam beragama.

\section{g. Membiasakan belajar sepanjang hayat (longlife education)}

Pendidikan sepanjang hayat sudah ada dalam hadist nabi yang berbunyi “Tuntutlah Ilmu Dari Buaian Hinga Liang Lahat”. Pernyataan ini sudah lama ada, namun baru diimplentasikan sekarang. Dalam pendidikan abad 21 belajar bukan hanya menjadi wacana namun harus diaplikasikan, sehingga mereka yang sudah tua diharuskan belajar walau tidak sehebat mengingat pada masa muda. Belajar tidak mengenal usia, oleh karenanya diharuskan bagi siswa maupun orangtua untuk selalu menggali informasi baik dengan cara membaca. Kebiasaan membaca harus ditanamkan pada anak didik, agar dapat menggali informasi yang ada pada abad yang dikenal dengan ajang kompetensi sumber daya manusia.

Abad 21 diharapakan mampu menjalankan fungsinya dalam membelajarkan manusia, agar tidak hanya belajar pada masa muda. Belajar merupakan salah satu cara untuk mengurangi kebodohan bangsa, untuk itu manusia diharapkan mampu menjalankan tugasnya sebagai Abdi di dalam Ard Tuhan. ${ }^{20}$ Tanpa belajar manusia tidak akan mampu mengenal bagaimana cara melaksanakan tugasnya sendiri, untuk itu manusia yang harus terus belajar tanpa ada kebosanan dalam diri.

\section{Elemen dan Karakteristik Pendidikan Sekolah Dasar/Madrasah Ibtidaiyah}

Dalam dataran pendidikan untuk mengembangkan sumber daya manusia harus ditopang dengan berbagai unsur yang berkaitan seperti lembaga yang diharapkan mampu mengembangkan dan mengasah demi mewujudkan kemampuan sumber daya manusia yang berkualitas agar selaras

20 Arief Furchan, Transformasi Pendidikan Islam di Indonesia: Anatomi Keberadaan Madrasah dan PTAI, Yogyakarta: Gama Media, 2004, hlm 23. 
dengan tujuan pendidikan. ${ }^{21}$ Tujuan pendidikan bukan hanya menjadi tugas guru namun kepala sekolah dan orangtua serta yang terkait dalam mewujudkan bangsa yang cerdas. Oleh karenanya tugas guru bukan hanya mampu mengajarkan namun mendidik anak didik sebenar-benarnya sesuai dengan pertumbuhan dan perkembangannya.

Pertumbuhan dan perkembangan setiap anak berbeda, ini terlihat dari perkembangan zaman. Perkembangan zaman yang sangat signifikan mewajibkan bagi guru untuk lebih berinovatif dalam proses pembelajaran tidak terkecuali guru SD/MI. ${ }^{22}$ Guru SD/MI diharapkan mampu mengembangkan potensi anak, karena awal pembelajaran melalui usia dasar, untuk itu guru harus mampu mengenal karakteristik dasar yang ada dalam diri anak didik sesuai perkembangan zaman yang selaras dengan pertumbuhan dan perkembangan. Perkembangan zaman yang dirasakan saat ini adalah perkembangan dalam mengakses informasi secara cepat dan mudah. Kemudahan inilah yang menimbulkan ajang kualitas sumber daya manusia.

Ada beberapa hal yang mendasar dalam pengembangan sumber daya manusia jenjang SD/MI. Pengembangan sumber daya manusia diharapkan mampu menaikkan mutu pendidikan dan keadilan bagi setiap sekolah. Oleh karenanya pemerintah harus mampu mengasah para pendidik dengan membuat pelatihan atau seminar untuk mengembangkan kemampuan dan kompetensi serta dapat menjadikan penambahan wawasan bagi guru yang terpencil. Keadaan sekolah yang buruk juga menjadikan salah satu faktor penghambat dalam mengembangkan dan menciptakan sumber daya manusia yang berkualitas, agar mampu bersaing dalam arus globalisasi.

${ }^{21}$ Tim PGRI, Pendidikan Untuk Transformasi Bangsa, Jakarta: PT Kompas Media Nusantara, 2014, hlm 67.

${ }^{22}$ Moh Padil dan Angga Teguh Prasetyo, Strategi Pengelolaan SD/MI Visioner. Malang: UIN Maliki Press, 2011, hlm.1. 
Era globalisasi sering disebut dengan era ketidakpastian. ${ }^{23}$ Maksudnya manusia selalu diminta berjalan seperti sistem agar dapat menyeimbangkan perdagangan atau perekonomian (hanya manusia yang memiliki kemampuan). Kemampuan yang diharapkan pada abad pengetahuan adalah kemampuan yang dapat menciptakan sumber daya manusia yang berkualitas tinggi dan unggul. Dengan kata lain manusia belajar harus memiliki skill untuk menjamin kehidupan (to guarantee life). Kehidupan bernegara terjamin bila manusianya mampu bersaing dengan negara lain, sehingga dimensi "ruang dan waktu" dapat dipergunakan demi menambah wawasan bukan menjadi jajahan.

Untuk itu hal mendasar yang harus dilakukan pendidik adalah merencanakan pendidikan sesuai dengan perkembangan zaman dan tantangan, agar dapat menyelaraskan sesuai perkembangan dan pertumbuhan anak didik. Anak didik notabenenya memiliki rasa ingin tahu yang kuat terhadap suatu pandangan atau pemahaman yang didengarkan, dilihat dan dirasakan. Oleh karenanya pendidik harus mampu menciptakan suasana belajar yang nyaman agar anak didik dapat belajar apapun yang mereka ingin ketahui, baik dari segi pengalaman, bacaan dan lain sebagainya untuk dapat menjadikan manusia pembelajar yang sesuai dengan konsep memanusiakan manusia.

\section{Relevansi Pendidikan yang Bermutu di Abad 21 dengan Kepemimpinan} Pendidikan dan Pengembangan Mutu Sumber Daya Manusia SD/MI

Pendidikan abad 21 sangat membutuhkan pembuktian kualitas. Oleh karenanya tugas lembaga harus lebih serius dalam membentuk dan mencetak intelektual cerdas yang mampu bersaing di era globalisasi. Era globaliasi dikenal dengan acceleration learning (pembelajaran yang cepat). ${ }^{24}$ Pembelajaran yang cepat diharapkan mampu menggugah kemampuan belajar

${ }^{23}$ Ace Suryadi. Pendidikan Investasi SDM...hlm 93.

${ }^{24}$ Sutrisno, Revolusi Pendidikan di Indonesia, Yogyakarta: Ar-Ruz Media, 2005, hlm 3. 
anak didik dalam proses pembelajaran serta dapat menciptakan suasana belajar yang menyenangkan. Pembelajaran yang menyenangkan (fun) seharusnya dapat membangun motivasi anak didik dalam proses belajar untuk menciptakan kegembiaraan serta dapat membentuk sumber daya manusia. Guru yang bertugas membentuk intelektual cerdas harus dapat menunjukkan kemampuan pedagogiknya. Oleh karena itu guru diharuskan membaca situasi dan kondisi zaman yang ada, agar dapat merealisasikan "konsep ilmu" sesuai dengan abadnya.

Abad yang dikenal dengan abad percepatan pengetahuan sudah tidak asing lagi didengar. Ini semua dibuktikan dengan berkembang pesatnya informasi (information), media (computer) dan teknologi (teknology). ${ }^{25}$ Oleh karenanya guru harus bekerja keras dalam membentuk bahan pelajaran yang selaras dengan perkembangan zamannya. Guru yang hebat adalah guru yang mampu menjadikan anak didiknya lebih cerdas darinya, untuk itu guru harus mempunyai inovasi-inovasi yang lebih kreatif dalam menciptakan suasana belajar, agar terciptanya manusia belajar serta mampu mewujudkan sumber daya manusia yang diinginkan.

Penelitian tentang bekerja dengan skill sangat diharuskan demi mensukseskan tujuan pendidikan Indonesia. Davies 2011 dalam penelitiannya menuliskan bahwa manusia dapat bersaing dengan komputer sekalipun, jikalau manusia mampu bekerja dengan menunjukkan keterampilan, dikarenakan segala teknologi dirancang oleh manusia. Dengan ini dapat ditarik kesimpulan bahwa semua manusia dapat menjadi terbaik bila mana manusia mampu bekerja keras dan membuktikannya.

\footnotetext{
${ }^{25}$ Ibid.,hlm 3-5
} 
Peran pendidik sangat sentral, dikarenakan sebaik apapun kurikulum dan sistem pendidikan tidak mampu dilaksanakan tanpa seorang pendidik yang bermutu.

Pendidik yang bermutu memiliki karakteristik diantaranya: mampu menuntaskan pembelajaran, upaya profesional dan mampu mengatur waktu. ${ }^{26}$ Untuk mampu merealisasikannya guru harus dapat menyesuaikan dengan keadaan zaman. Maksudnya perbedaan suasana belajar setiap masanya harus dipikirkan oleh guru untuk menciptakan suatu metode atau dengan mengembangkan berbagai metode yang ada, baik dengan menginovasinya atau mengkreasikannya dalam proses pembelajaran.

Pernyataan di atas selaras dengan pendapat Savedra dan Opfer yang menyatakan bahwa:

Pendidikan abad 21 memiliki bebebarapa prinsip diantaranya: Mengintegrasikan pembelajaran, disiplin, membangun berpikir kritis, menanamkan perbedaan pemahaman, menanamkan jiwa belajar untuk terus belajar (sepanjang hayat), mengakui kesalahanpahaman secara langsung (peace to peace), membangun kerjasama, memanfaatkan kegunaan teknologi, meningkatkan kretavitas dalam proses pembelajaran dan tidak bakhil ilmu. ${ }^{27}$

Pernyataan Savedra dan Opfer didukung oleh Badan Standar Nasional Pendidikan (BNSP) yang menyatakan bahwa:

Setidaknya untuk meningkatkan persaingan kompetensi abad 21 guru harus mampu mengembangkan potensi anak didik dengan menjadi fasilitator yang memiliki jiwa inovasi, meningkatkan kreativitas dalam proses pembelajaran, menamkan literasi digital (teknologi, media dan informasi) serta mampu berkerjasama secara bersama. ${ }^{28}$

${ }^{26}$ Hamid Darmadi, Metode Penelitian Pendidikan, Bandung: Alfabeta, 2011, hlm 6-17.

27 Opfer V and Saavedra A. Teaching and Learning 21st Century Skills: Lessons from the Learning Sciences a Global Cities Education Network Report. New York, Asia Society.

${ }^{28}$ Badan Standar Nasional Pendidikan. Paradigma... hlm 56-57. 
Berdasarkan dua proposisi di atas dapat disimpulkan bahwa dalam mewujudkan sumber daya manusia jenjang Sekolah Dasar atau Madrasah Ibtidayyah, seorang pendidik harus memiliki prinsip untuk meningkatkan kualitas sumber daya manusia agar mampu bersaing dalam arus globalisasi. Era globalisasi tidak membutuhkan banyak teori namun lebih pada kualitas sumber daya manusia dalam memecahkan masalah. Oleh karenanya tugas pendidik yaitu harus mampu mengkoneksikan berbagai ilmu untuk memudahkan siswa dalam memahami pembelajaran agar terciptanya manusia belajar.

Untuk menjawab relevansi atau keterkaitan abad 21 dalam mengembangkan sumber daya manusia, pendidik harus mampu memanfaatkan teknologi untuk mencari sumber informasi, berkomunikasi dan bekerjasama, kreatif dalam proses pembelajaran, menanamkan literasi, menghargai pendapat dan berfikir kritis, mengembangkan berbagai pembelajaran secara inovatif dan menjadi manusia pembelajar sesuai dengan konsep pendidikan sepanjang hayat. Hal ini sudah menjadi keharusan bagi pendidik dalam membentuk sumber daya manusia berkualitas, yang dapat diuraikan sebagai berikut:

\section{a. Memanfaatkan Teknologi untuk mencari sumber informasi}

Perkembangan teknologi menjadikan manusia lebih mudah dalam mendapatkan informasi dan menjadi kecanduan. Maksudnya semakin mudah mengakses informasi seharusnya bukan menjadi problem bagi pendidik, melainkan memudahkan dan membantu pendidik untuk mengkonsep materi dalam proses pembelajaran. Oleh karenanya perkembangan teknologi harus dipergunakan sebaik mungkin untuk meningkatkan sumber daya manusia agar mampu bersaing dalam membuktikan kualitas suatu bangsa. 
Davies dan Furlong 2012 menyatakan dalam penelitiannya bahwa suatu bangsa dikatakan maju, terlihat ketika bangsa itu mampu mengendalikan teknologi. ${ }^{29}$ Maksudnya semakin hebat dan jayanya suatu bangsa terlihat dalam menggunakan teknologi, ketika suatu bangsa mampu mengendalikan teknologi bangsa dihargai dan dihormati. Untuk itu pendidik harus mampu menggunakan teknologi guna membelajarkannya pada diri anak didik sesuai dengan pertumbahan dan perkembangannya.

\section{b. Berkomunikasi dan Bekerjasama}

Untuk mampu berintraksi, guru harus mampu berkomunikasi secara baik. Berkomunikasi pada abad 21 bukan perkara mudah, karena pada abad ini dianjurkan untuk memahami bahasa untuk memudahkan berbicara. Bahasa yang umumnya dipergunakan adalah bahasa dunia (Inggris dan Arab). Setelah mampu berbahasa memudahkan bagi manusia untuk menjalin kerjasama atau menjalin hubungan (nasional maupun internasinal) berbagai pihak.

Pemahaman di atas sesuai dengan hasil riset Bolstad 2011 yang menuliskan bahwa fokus terhadap bahasa merupakan salah satu tugas guru untuk membelajarkannya kepada siswa untuk mampu menyaingi dan mengalahkan bangsa-bangsa maju.

\section{c. Kreatif dalam proses pembelajaran}

Abad 21 diharapkan bagi guru untuk mampu menciptakan intelektual yang cerdas agar mampu bersaing. Oleh karenanya tugas guru adalah mampu mengelola kelas dan membuat suasana belajar yang nyaman, agar dapat memudahkan anak didik dalam memahami materi. Materi yang diajarkan harus dapat diintegrasikan dalam berbagai ilmu dengan menggunakan metode yang baru. Scott 2015 dalam penelitiannya menjelaskan bahwa perubahan

${ }^{29}$ Davies and Furlong, J.C. Young People, New Technologies and Learning at Home: Taking Context Seriously, Oxford Review of Education, Vol. 38, No.1, 2012, hlm 21. 
metode untuk mengajar sangat diharuskan untuk menjadikan anak aktif dan mau belajar sesuai dengan perkembangan dan pertumbuhan yang dialami.

\section{d. Menanamkan literasi}

Penanaman literasi ini diharapkan mampu memotivasi anak didik dalam mencari informasi dan memudahkan siswa dalam memahami suatu materi. Dengan ini guru harus mampu menanamkan jiwa membaca pada diri anak didik untuk lebih giat, agar tidak mudah didoktrin oleh pemikiranpemikiran, sehingga anak didik nantinya mampu menjalankan tugas sebagai manusia yang cerdas sesuai dengan tujuan pendidikan abad 21 yaitu membutuhkan kualitas bukan kuantitas. Scott 2015 dalam penelitiannya menyatakan bahwa berbicara pendidikan bukan hanya tentang bagaimana belajar, namun bagaimana guru itu mampu menimbulkan jiwa literasi dalam diri anak untuk menambah sutau pemahaman yang mendalam.

\section{e. Menghargai pendapat dan berfikir kritis}

Memahami situasi dan kondisi pada abad 21 memudahkan pendidik untuk mengembangkan potensi yang ada dalam anak didik. ${ }^{30}$ Anak didik juga diharapkan mampu melihat minat dan memahami bakat yang ada di dalam dirinya, agar guru mampu mengembangkan potensi pada dirinya. Oleh karenanya guru harus dapat mengkonsep untuk mengembangkan kepribadian anak didik dalam menyampaikan sesuatu. Perbedaan berpendapat pasti selalu terjadi dalam era globalisasi. Era globalisasi ditandai dengan berkembangnya teknologi dan mudahnya mencari informasi. Informasi yang didapat menjadi acuan dalam memahami sesuatu. Untuk itu tugas guru harus menanamkan nilai menghargai dalam berpendapat kepada anak didiknya agar tidak terjadi kesalahpamahan. Perbedaan ras, suku dan budaya mengakibatkan kekacauan bilamana tidak dapat memahaminya.

30 Nurdin Mansur, Penerapan Keterampilan Mengajar Dalam Upaya Pencapaian Hasil Belajar Mahasiswa, Lantanida Journal, Vol. 4 No. 2, 2016, hlm 4. 
Agar dapat menyelaraskan perihal di atas, guru harus dapat menanamkan nilai berfikir kritis pada diri anak didik, agar tidak mudah mempercayai suatu hal, sebelum mencari dan menganalisisnya sendiri. Oleh karenanya pendidik yang benar adalah pendidik yang mampu mengembangkan potensi anak didiknya sesuai dengan perkembangan dan pertumbuhan. Untuk itu tugas guru bukan hanya mendidik namun menanamkan jiwa berfikir kritis dan mengharagai pendapat orang lain, agar tidak terjadi benturan atau perkelahian dalam memahami suatu pandangan.

\section{f. Mengembangkan berbagai pembelajaran secara inovatif}

Pembaharuan pembelajaran yang dialami setiap tahunnya membuat pendidik harus lebih cerdas dalam memahami perkembangan yang ada, dengan tidak meninggalkan metode atau teknik lama (tradisional), namun sebaliknya mampu mengembangkannya dengan menginovasi metode tersebut, agar memudahkan dalam menyampaikan proses pembelajaran. Guru yang cerdas adalah guru yang mampu membuat inovasi-inovasi terbaru untuk mengembangkan potensi anak didik sesuai dengan perkembangan dan pertumbuhan, dikarenakan setiap anak memiliki kemampuan yang berbeda dalam menyelesaikan masalah.

Tugas guru bukan lagi mendidik namun melatih agar mampu mengembangkan dan mengkoneksikan potensi anak sesuai dengan perkembangannya. Oleh karenanya guru harus dapat bercengrama dan bergaul dengan mendekati anak didik, bukan menakuti-nakutinya. Guru yang hebat mampu menjadikan anak didiknya teman dalam berinteraksi agar tercipta masyarakat belajar. Belajar yang baik adalah belajar dengan nyaman, tanpa ada unsur ketakutan di dalamnya. Agar terciptanya pembelajaran yang menyenangkan guru diharapkan memiliki jiwa inovatif dalam proses 
pembelajaran sesuai dengan perkembangan zaman yang selaras dengan pertumbuhan dan perkembangan anak didik.

\section{g. Menjadi Manusia Pembelajar sesuai dengan konsep belajar sepanjang} hayat

Dalam tataran pendidikan terkhusus pada abad 21 yang disebut dengan abad pengetahuan untuk memanusiakan manusia bukan pekerjaan yang mudah bagi pendidik. Memang benar tugas pendidik adalah mengajarkan manusia sesuai dengan tujuan pendidikan. Tujuan pendidikan yang bertujuan untuk mencetak bangsa yang cerdas harus ditopang dengan kualitas mutu sumber daya manusia. Sumber daya manusia yang berkualitas terlihat dalam bangsa yang besar dan maju. Hal ini sesuai dengan penelitian Barret 2014 yang menyatakan bahwa kemajuan suatu bangsa terlihat ketika sumber daya manusianya mau terus belajar terutama di era teknologi. Kemajuan ilmu teknologi diharapkan memudahkan manusia untuk belajar sesuai dengan kebutuhan mendasar dalam menciptakan sumber daya manusia yang berkualitas pada abad yang menunjukkan keahlian atau kompetensi.

Kompetensi yang diharapkan adalah kompetensi yang sesuai dengan kebutuhan abad ini. Berbeda dengan abad sebelumnya yang mampu merubah tata kehidupan. Kehidupan saat ini sudah menjadi keharusan setiap orang dalam belajar untuk mengasah bakat yang dimiliki. Maksudnya sudah tugas setiap manusia untuk belajar agar mampu bersaing dan berkompetisi dengan bangsa lain.

\section{SIMPULAN}

Perkembangan ilmu pengetahuan dan teknologi bukan menjadi hambatan bagi pendidik, melainkan memberikan kemudahan dalam mengakses informasi. Informasi yang dimaksud adalah pengetahuan. Untuk mencetak intelektual atau sumber daya manusia berkualitas serta dapat bersaing dalam era globalisasi tidaklah mudah. Oleh 
karenanya tugas guru pada abad 21 berat bila tidak melihat perkembangan zaman, namun mudah jika pendidik mampu berorientasi pada perkembangan zaman yang ada serta dapat menyelaraskan dengan perkembangan dan pertembuhan anak didik. Hal yang diutamakan pada abad 21 adalah sumber daya manusia yang bermutu, untuk itu pendidik harus lebih aktif memberdayakan teknologi. Pemberdayaan teknologi memudahkan bagi guru untuk menjalankan fungsinya yaitu mengajar dan mendidik. Pendidik abad 21 diharapkan mampu merancang pembelajaran yang inovatif sehingga menciptakan suasana belajar yang nyaman dan tenang, agar memudahkan anak didik dalam mewujudkan cita-citanya sebagai pembaharuan dalam dunia pendidikan dan dapat bersaing di kancah Internasional. 


\section{DAFTAR PUSTAKA}

Ananiadou Katrina and Cloro Magdalean, 21 st Century Skills and Competences for New Millennium Learners in OECD Countries, OECD Education Working Papers, No. 41. Paris, OECD Publishing, 2009.

A, P. Mangkunegara, Perencanaan dan Pengembangan Sumber Daya Manusia. Bandung: Rifeka Aditama, 2011.

A Saavedra and V, Opfer, Teaching and Learning 21st Century Skills: Lessons from the Learning Sciences a Global Cities Education Network Report. New York, Asia Society, 2012.

Badan Standar Nasional Pendidikan, Paradigma Pendidikan Nasional Di Abad-21, Jakarta: BSNP, 2010.

Barrett, M., Byram, M., Lázár, I., Mompoint-Gaillard, P. and Philippou, S, Developing Intercultural Competence through Education. Pestalozzi Series No.3. Strasbourg, Council of Europe Publishing, 2014.

Bolstad, R, Taking a 'Future Focus' in Education - What Does It Mean? NZCER Working Paper, Wellington, New Zealand Council for Educational Research, 2011.

Davies, A., Fidler, D. and Gorbis, M, Future Work Skills 2020. Palo Alto, Calif., University of Phoenix Research Institute, 2011.

Darmadi, Hamid, Metode Penelitian Pendidikan. Bandung: Alfabeta, 2011.

Furchan, Arief, Transformasi Pendidikan Islam di Indonesia: Anatomi Keberadaan Madrasah dan PTAI. Yogyakarta: Gama Media, 2004.

Furlong, J.C, and Davies, Young People, New Technologies and Learning at Home: Taking Context Seriously (Oxford Review of Education, Vol. 38, No.1, 2012.

Georgia Stepghanou and Maria-Helena Mpiontini, Metacognitive Regolution in-SelfRegulatory Learning Style, and Its Effects on Performance Expectation and Subsequent Performance across Diverse School Subject. Journal Psychology, Vol.8, No.12, 2017. 
Hermawan, Herry Asep, Pengembangan Kurikulum dan Pembelajaran. Jakarta: UT Departemen Pendidikan Nasional, 2006.

Machali, Imam, Didin Kurniadin, Manajemen Pendidikan: Konsep dan Prinsip Pengelolaan Pendidikan. Jogyakarta: Ar-Ruzz Media, 2014.

Mansur, Nurdin, Penerapan Keterampilan Mengajar Dalam Upaya Pencapaian Hasil Belajar Mahasiswa. Lantanida Journal, Vol. 4 No.2, 2016.

McLoughlin, Catherine, Lee, and Mark J.W, The three p's of pedagogyfor the networked society: personalization, participation, and productivity. International Journal of Teaching and Learning in Higher Education, Vol. 20, No.1, 2008.

Nyoto, Amat, Sudjimat Dwi Agus dan Etiska Ayu Wijaya, Transformasi Pendidikan Abad 21 sebagai Tuntunan Pengembangan Sumber Daya Manusia di Era Global. Jurnal: Universitas Negeri Malang, Volume 1, 2016.

Prasetyo, Angga Teguh dan Moh Padil, Strategi Pengelolaan SD/MI Visioner. Malang: UIN Maliki Press, 2011.

Prastowo, Andi, Menyusun Rencana Pelaksanaan Pembelajaran (RPP) Tematik Terpadu. Jakarta: Kencana, 2015.

RI Dapartemen, Al-Qur'an dan Terjemah. Bogor: Sygma Exagrafika, 2007.

Ridwan dan Damayanti, Isu dalam Sains dan Agama. Yogyakarta: Universitas Islam Negeri Sunan Kalijaga, 2006.

Roberto, Carneiro. and Alexandria, Draxler, Education for the 21st century: lessons and challenges, European Journal of Education, Vol. 43, No.2, 2008.

Sastrapraredja, Y. M, Pendidikan Multidimensional. Yogyakarta: Sanata Dharma University Press, 2015.

Scott, C.L, The Futures of Learning 1: Why must learning content and methods change in the 21st century?, UNESCO Education Research and Foresight, Paris. ERF Working Papers Series, No.13, 2015. 
Scott, C.L, The Futures of Learning 2: What kind of learning for the 21st century? UNESCO Education Research and Foresight, Paris. ERF Working Papers Series, No. 14, 2015.

Sjafriani, Ririn, Pendidikan Global: Menggunakan Teknologi untuk Memperkenalkan Dunia Global kepada Para Siswa. Jakarta: Indeks, 2011.

Sudriarja, A, Pendidikan dalam Tantangan Zaman. Yogyakarta: Kanisius, 2014.

Suryadi, Ace, Pendidikan, Investasi SDM, dan Pembangunan. Jakarta: Balai Pusataka, 2002.

Sutrisno, Revolusi Pendidikan di Indonesia. Yogyakarta: Ar-Ruzz Media, 2005.

Tim PGRI, Pendidikan Untuk Transformasi Bangsa. Jakarta: PT Kompas Media Nusantara, 2014.

Trilling, Bernie and Fadel, Charles, 21st Century Skills: Learning for Life in Our Times, John Wiley \& Sons, 978-0-47-055362-6, 2009. 